\title{
Detection of Vibrio anguillarum from Waters
}

\author{
Kiyokuni Muroga,* Masahiko Iida, ${ }^{*}$ Hiroyuki Matsumoto,* \\ and Toshihiro Nakai* \\ (Accepted August 30, 1985)
}

\begin{abstract}
Detections of Vibrio anguillarum from freshwater of ayu Plecoglossus altivelis culture ponds and sea water of the Inland Sea of Japan were made by a two-step culture method consisting of alkaline peptone water and BTB teepole agar. As the results, $V$. anguillarum was often detected from sea waters especially when water temperature was below $20^{\circ} \mathrm{C}$, but not from freshwaters in spite of the occurrence of vibriosis in some ponds.

Among 89 isolated strains of $V$. anguillarum, only 13 strains belong to the known serotypes form A to I, and 8 strains were pathogenic to ayu or Japanese eel Anguilla japonica.

It was demonstrated by in vitro experiments that the organism persisted in sea water but perished within 3 to $5 \mathrm{~h}$ in freshwater.
\end{abstract}

Vibrio anguillarum has been reported as a disease agent from various species of fish in the world. The organism is considered to be a facultative fish pathogen, ${ }^{1)}$ thus it must be ubiquitous in the environment of the fish. However, the ecology of this fish pathogen in waters has not been fully investigated so far.

In this study, we examined the presence of $V$. anguillarum in ayu Plecoglossus altivelis culture ponds and the Inland Sea of Japan and its adjacent areas. As the results, $V$. anguillarum was detected from the sea water but not from the freshwater of ayu ponds. The isolates from sea waters were tested of their pathogenicity and serotype.

\section{Materials and Methods}

\section{Detection Method}

A two-step culture method consisting of alkaline peptone water and BTB teepol agar, which was used in the previous investigation on carriage of $V$. anguillarum in fingerlings of ayu, ${ }^{2)}$ was employed in this study with a slight modification. Based on the following recovery test, $\mathrm{NaCl}$ concentration of alkaline peptone water (APW) was modified from $3 \%$ to $0.5 \%$ for the detection of the organism from sea water samples. Two strains (PSH-8001: Serotype A, ${ }^{3)}$ isolated from diseased ayu, HT-78001: Serotype C from diseased yellowtail Seriola quinqueradiata) were inoculated into $1 l$ of non-sterilized freshwater (ayu-pond water) and sea water with various concentrations $\left(10^{\circ}\right.$
$10^{6} \mathrm{CFU} / \mathrm{m} l$ ). Each of the inoculated water was immediately filtered and the applied membrane filter $(0.45 \mu \mathrm{m})$ was put into APW with 0.5 or $3 \%$ $\mathrm{NaCl}$. After $18-24 \mathrm{~h}$ incubation, one loopful of the APW culture was spread on BTB teepol agar, and the recovery of the inoculated $V$. anguillarum was determined by colony morphology on the agar plate and the slide agglutination test against the corresponding antisera. According to the results of the above recovery test, the detection

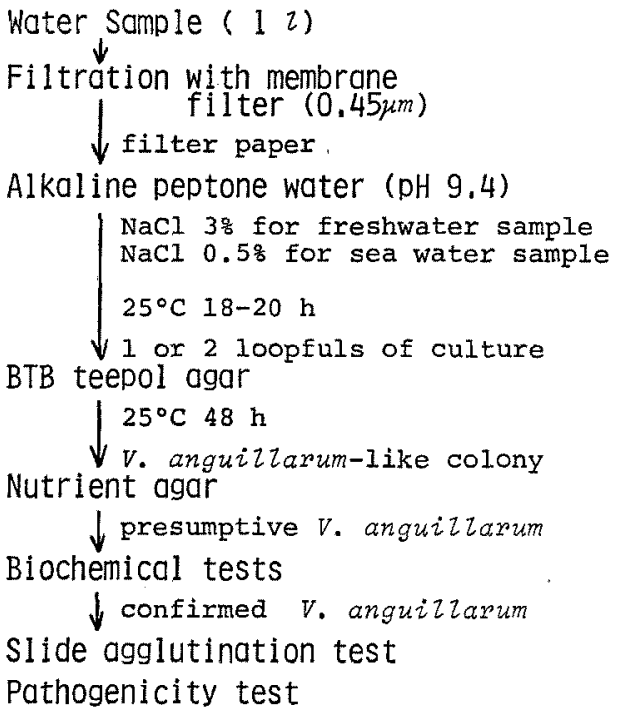

Fig. 1. Method for the detection of Vibrio anguillarum from waters.

* Faculty of Applied Biological Science, Hiroshima University, Fukuyama 720, Japan (室賀清邦, 飯田正彦, 松本浩幸, 中井敏博: 広島大学生物生廒学部). 
method of $V$. anguillarum for the present study was determined as summarized in Fig. 1.

\section{Detection from Freshwater}

In July of 1983, detection of $V$. anguillarum was made from freshwater of ayu culture ponds in Tokushima Prefecture. Each $1 l$ of pond water was obtained at 11 ayu farms and added with $\mathrm{NaCl}$ immediately to furnish the concentration of $0.85 \%$ and kept in an ice box for 3-5 h until submitted to the bacterial detection shown in Fig. 1. These treatments were conducted to support the survival of $V$. anguillarum based on the survival tests shown later. At the same time, 10 dead fish were collected at each pond and the spleen material of each fish was streaked on nutrient agar.

\section{Detection from Sea Water}

Four times of research cruises were made by Toyoshio-maru $(330 \mathrm{t})$, a research vessel of Hiroshima University, in May and July of 1983 and 1984 in the Inland Sea of Japan and its adjacent areas shown in Fig. 2. In each cruise, surface $(50 \mathrm{~cm} \sim 1 \mathrm{~m}$ depth) and bottom (about $2 \mathrm{~m}$ above the bottom) water samples were obtained at 8 to 14 stations, and the collected samples were filtered and inoculated in APW on board. Water temperature, $\mathrm{pH}$, and salinity of each sample were measured in every cruise and COD (chemical oxygen demand) and SS (amount of suspended solid) were determined in the second and the last cruise, respectively.

From April 1984 to January 1985, the presence of the bacterium in the sea water pumped up for fish rearing tanks was monitored monthly at Hiroshima Fish Farming Center, Takehara City. At the center, sand-filtered and non-filtered waters were supplied, and both were examined separately.

\section{Characterization of Isolates}

The isolates, which were presumed to be $V$. anguillarum from their colony morphology on BTB teepol and nutrient agars, were submitted to biochemical characterization tests. As the result, 89 isolates were confirmed to be classified as $V$. anguillarum and these strains were tested of their serotype by slide agglutination with anti- $V$. anguillarum rabbit sera, $\mathrm{A} \sim \mathrm{I}^{3,4)}$ Sixty strains out of the 89 strains were tested of their pathogenicity by intramuscular injection against juvenile ayu (average body weight $4 \mathrm{~g}$ ) or Japanese eel Anguilla japonica $(83 \mathrm{~g})$.

\section{In Vitro Experiments on Survival of $V$. anguillarum in Waters}

Two strains of $V$. anguillarum (PT-81049:

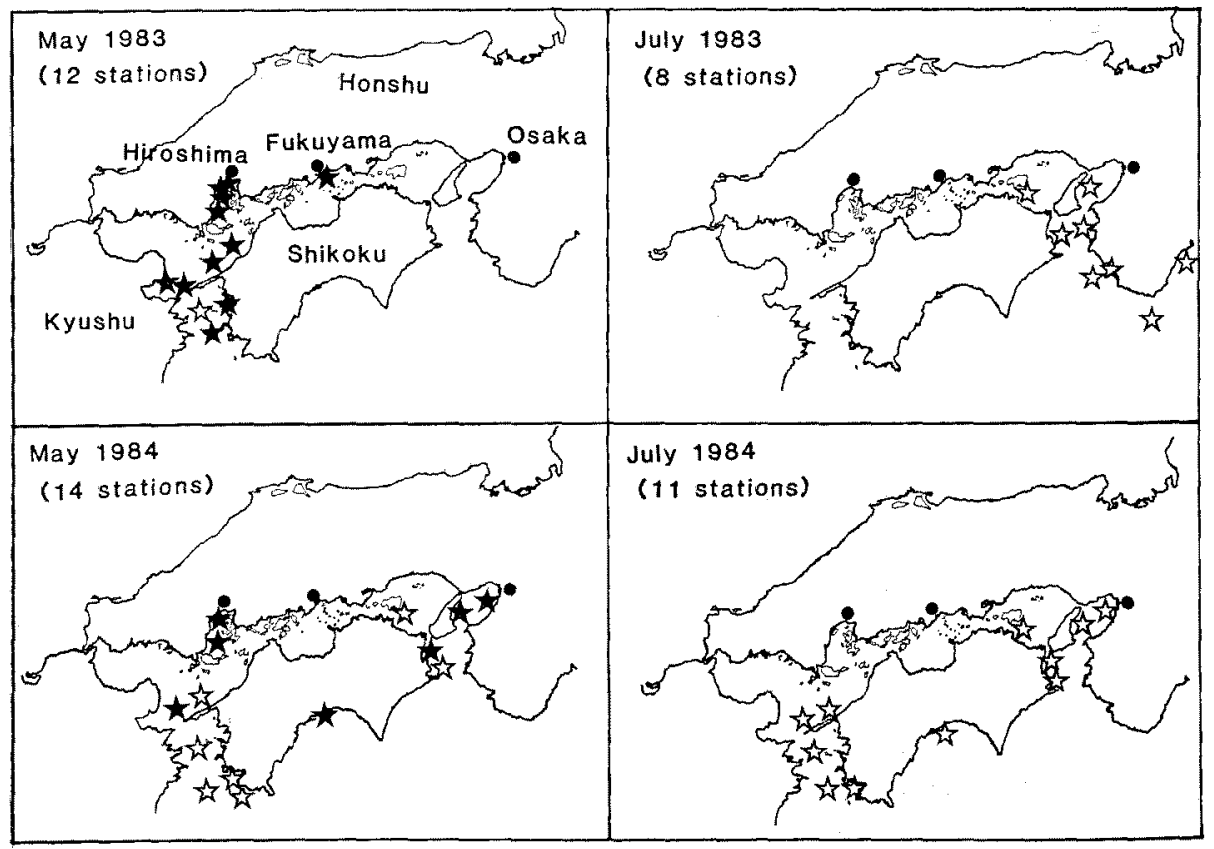

Fig. 2. Sampling stations and results of the detection of $V$. anguillarum in the Inland Sea of Japan. $\star$ : positive, $t:$ negative 
Serotype A, PT-213: C, both were isolated from diseased ayu) were inoculated into sterilized sea water, freshwater, normal saline $(0.85 \% \mathrm{NaCl})$ and distilled water at about $10^{4} \mathrm{CFU} / \mathrm{m} l$, and each water was kept at $20^{\circ} \mathrm{C}$. Number of viable cells of the organism was monitored for $3 \mathrm{~h}$ by plate culture method. In addition, the survival of one strain (PT-81049) in sea water and freshwater was studied at various temperatures from 5 to $35^{\circ} \mathrm{C}$.

\section{Results}

The Effect of $\mathrm{NaCl}$ Concentration of $\mathrm{APW}$ on the Recovery of $V$. anguillarum

The result of the recovery test is given in Table 1. It was revealed that the organism was recovered efficiently from sea waters when $0.5 \%$ $\mathrm{NaCl}$ APW was used. On the other hand, $3 \%$ $\mathrm{NaCl}$ APW gave better results than $0.5 \% \mathrm{NaCl}$ in freshwater samples. The lowest inoculation level resulting in positive detection was $10^{1}$ and $10^{4}$ $\mathrm{CFU} / l$ in the sea water and the freshwater, respectively.

\section{Detection from Freshwater}

Table 2 shows the result of the detection of $V$. anguillarum from ayu pond waters. The pathogen was isolated from dead fish at 4 ponds, thus vibriosis occurred in these 4 ponds. However, the pathogen could not be detected from any water samples including those of the above 4 ponds.

\section{Detection from Sea Water}

The organism was detected at the two cruises made in May but not in July in both years (Fig. 2). The bacterium tended to be detected in bays with progressed eutrophication, however, significant

Table 1. The Effect of $\mathrm{NaCl}$ concentration of alkaline peptone water (APW) on the recovery of Vibrio anguillarum (PSH-8001, HT-78001) from freshwater and sea water

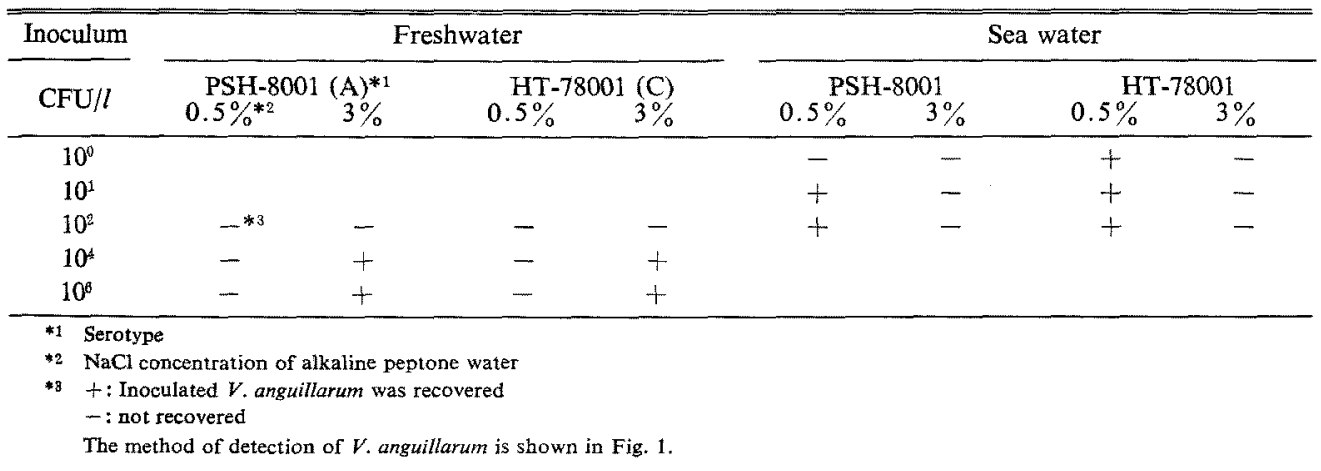

Table 2. Detection of $V$. anguillarum from freshwater of ayu culture ponds

\begin{tabular}{cccc}
\hline Pond & $\begin{array}{c}\text { Water } \\
\text { temperature } \\
\left({ }^{\circ} \mathrm{C}\right)\end{array}$ & $\begin{array}{c}\text { Detection } \\
\text { of } V . \\
\text { anguillarum } \\
\text { from-water }\end{array}$ & $\begin{array}{c}\text { Isolation } \\
\text { of } V . \\
\text { anguillarum } \\
\text { from dead } \\
\text { ayu }\end{array}$ \\
\hline 1 & 19.4 & - & $-(0 / 10)$ \\
2 & 19.8 & - & $-(0 / 10)$ \\
3 & 19.5 & - & $+(10 / 10)$ \\
4 & 19.9 & - & $-(0 / 1)$ \\
5 & 20.8 & - & $+(10 / 10)$ \\
6 & 16.5 & - & $-(0 / 10)$ \\
7 & 17.4 & - & $+(1 / 10)$ \\
8 & 21.7 & - & $-(0 / 10)$ \\
9 & 18.4 & - & $-(0 / 10)$ \\
10 & 20.4 & - & $+(6 / 7)$ \\
11 & - & - & $-(0 / 10)$ \\
\hline
\end{tabular}

Table 3. Detection of $V$. anguillarum from sea waters at Hiroshima Prefectural Fish Farming Center at Takehara

\begin{tabular}{|c|c|c|}
\hline \multirow{2}{*}{$\begin{array}{c}\text { Date } \\
(1984-1985)\end{array}$} & \multicolumn{2}{|c|}{$\begin{array}{l}\text { Result of detection of } \\
V . \text { anguillarum from }\end{array}$} \\
\hline & $\begin{array}{l}\text { Non-filtered } \\
\text { sea water }\end{array}$ & $\begin{array}{l}\text { Sand-filtered } \\
\text { sea water }\end{array}$ \\
\hline 25, Apr. & $+\left(12.3^{\circ} \mathrm{C}\right)^{*}$ & $+\left(13.1^{\circ} \mathrm{C}\right)$ \\
\hline 15, May & $+(14.0)$ & $-(14.5)$ \\
\hline 6, Jun. & $+(17.4)$ & $-(17.9)$ \\
\hline 26, Jun. & $-(19.4)$ & $+(19.6)$ \\
\hline 23, Jul. & $-(22.3)$ & $-(22.5)$ \\
\hline 23, Aug. & $-(25.1)$ & $-(26.5)$ \\
\hline 28 , Sept. & $-(24,0)$ & $-(24.1)$ \\
\hline 17, Oct. & $+(22.8)$ & $-(22.3)$ \\
\hline 21, Nov. & $+(13.4)$ & $+(19.0)$ \\
\hline 12, Dec. & $+(17.0)$ & $+(17.0)$ \\
\hline 17, Jan. & $+(12.2)$ & $+(12.0)$ \\
\hline
\end{tabular}


relationships between the presence of $V$. anguillarum and COD or SS values were not verified.

The result of $V$. anguillarum detection at Hiro-

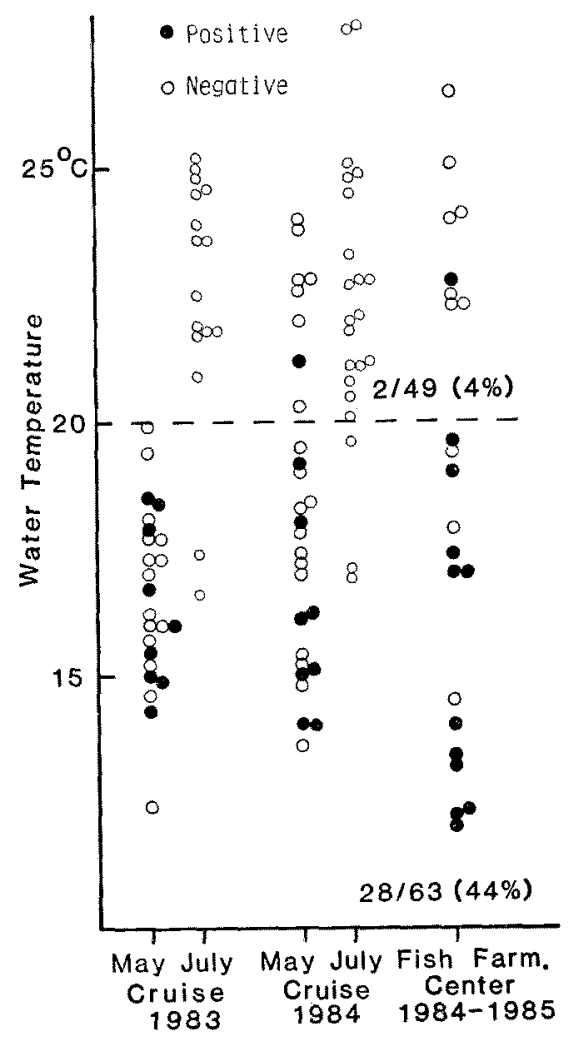

Fig. 3. Relationship between the results of $V$. anguillarum detection and water temperatures. shima Prefectural Fish Farming Center is given in Table 3. Although there were some discrepancies in the results between non-filtered and sandfiltered waters, however, it is remarkable that $V$. anguillarum could not be detected from July to September when water temperature exceeded $20^{\circ} \mathrm{C}$. Putting all together these results with those obtained by the research cruises, the relationship between the results of $V$. anguillarum detection and water temperature is demonstrated in Fig. 3. The positive rate of the detection in the samples whose temperatures were below $20^{\circ} \mathrm{C}$ was much higher $(44 \%)$ than that of the samples of the higher temperatures $(4 \%)$.

\section{Characterization of $V$. anguillarum Isolates}

Based on biochemical characteristics, 89 isolates were confirmed to be $V$. anguillarum, and the characters of these isolates are listed in Table 4. Among the isolates which were presumed as $V$, anguillarum from their colony appearance, some were eliminated finally from $V$. anguillarum due to inappropriate reactions in some important tests such as arginine decomposition and acetylmethycarbinol production (VP test).

Out of 89 strains only 13 strains belonged to the known serotypes from A to I (Table 5), and the remaining 76 strains $(85 \%)$ could not be sorted serologically.

Table 6 shows the results of pathogenicity tests on 60 strains. Among the tested strains, 8 strains $(13 \%)$ were pathogenic for ayu or eel. There seemed to be no relationship between pathogenicity and serotype, so far as the present results were

Table 4. Characteristics of $V$, anguillarum 89 strains isolated from sea waters

\begin{tabular}{lccc}
\hline \multicolumn{1}{c}{ Test } & Result & Test & Result \\
\hline Motility & + & Starch hydrolysis & + \\
OF test & Fermentative & Citrate (Simmons) & + \\
Gas from glucose & - & $\beta$-galactosidase (ONPG) & + \\
Cytochrome oxidase & + & Acid from adonitol & - \\
Sensitivity to O/129 & + & arabinose & $+(76)$ \\
novobiocin & + & cellobiose & $+(94)$ \\
Nitrate reduction & + & fructose & + \\
Gelatin liquefaction & + & glucose & + \\
Indole production & + & lactose & + \\
Voges-Proskauer test & + & maltose & + \\
Methyl red test & $-(98)^{*}$ & mannitol & + \\
2,3-butanediol production & + & mannose & + \\
Hydrogen sulfide & - & sucrose & + \\
Arginine decomposition & + & trehalose & + \\
Lysine decarboxylation & - & NaCl tolerance $0 \%$ & $7 \%$ \\
Ornithine & - & & $-(91)$ \\
\hline
\end{tabular}

* ( ): \% having reactions as given 
concerned.

\section{Survival in Waters}

Fig. 4 shows that both serotypes of $V$. anguil-

Table 5. Serotype of $V$. anguillarum 89 strains isolated from sea waters

\begin{tabular}{cccc}
\hline \hline Serotype* & $\begin{array}{c}\text { 54 strains } \\
\text { from cruise } \\
\text { May, 1983 }\end{array}$ & $\begin{array}{c}15 \text { strains } \\
\text { from cruise } \\
\text { May, 1984 }\end{array}$ & $\begin{array}{c}\text { 20 strains } \\
\text { from Fish } \\
\text { Farm Center }\end{array}$ \\
\hline A & 0 & 0 & 1 \\
B & 0 & 0 & 0 \\
C & 0 & 0 & 0 \\
D & 1 & 0 & 0 \\
E & 0 & 0 & 0 \\
F & 1 & 2 & 1 \\
G & 0 & 0 & 6 \\
H & 1 & 0 & 0 \\
I & 0 & 0 & 0 \\
Others & 51 & 13 & 12 \\
\hline
\end{tabular}

Table 6. Pathogenicity of $V$. anguillarum 60 strains isolated from sea waters

\begin{tabular}{|c|c|c|}
\hline \multirow{2}{*}{ Strains } & \multicolumn{2}{|c|}{ Pathogenicity*1 } \\
\hline & + & - \\
\hline $\begin{array}{l}54 \text { strain from } \\
\text { cruise May } 1983\end{array}$ & $\begin{array}{c}6 \\
(\text { Others- } 6)^{* 2}\end{array}$ & $\begin{array}{l}\quad 48 \\
\text { (D-1, F-1, H-1, } \\
\text { Others-45) }\end{array}$ \\
\hline $\begin{array}{l}6 \text { strains from } \\
\text { Fish Farm. } \\
\text { Center }\end{array}$ & (A-1, Others-1) & $\begin{array}{l}\quad 4 \\
\text { (F-1, G-1, } \\
\text { Others-2) }\end{array}$ \\
\hline \multicolumn{3}{|c|}{$\begin{array}{l}\text { Fish were killed }(+) \text {, or not killed }(-) \\
\text { Five ayu were injected intramuscularly with } 10^{2} \mathrm{CFU} / \text { issh } \\
\text { of each strain from the cruise, and } 2 \text { eels were injected } \\
\text { intramuscularly with } 10^{\circ} \mathrm{CFU} / 100 \mathrm{~g} \text { BW of each strain } \\
\text { from Fish Farming Center. } \\
\text { Serotype }\end{array}$} \\
\hline
\end{tabular}

larum died within $3 \mathrm{~h}$ in the freshwaters but survived without any decrease in viable cell number in the sea water for at least $3 \mathrm{~h}$. Addition of $\mathrm{NaCl}(0.85 \%)$ to distilled water remarkablly enhanced the survival of the organism.

The effects of water temperature on the survival of PT-81049 strain in sea water and freshwater are shown in Figs. 5 and 6, respectively. In both cases, the organism survived the longer period at the lower temperature, however, it could hardly survive in freshwater.

\section{Discussion}

We already reported that wild fingerlings of ayu, which were caught in freshwater and marine environments as seedlings for pond culture, harbored $V$. anguillarum at certain percentages, and these carrier fish were thought to be the source of the infection in freshwater ponds. ${ }^{2)}$ In that study, $3 \% \mathrm{NaCl}$ APW (alkaline peptone water) was adopted for the detection because a satisfactory result was obtained in a preliminary recovery test using ayu fingerlings caught in freshwater environment, though the result was not presented there. In this study, the $\mathrm{NaCl}$ concentration of APW was determined to $3 \%$ and $0.5 \%$ for the detection of $V$. anguillarum from freshwater and sea water, respectively. It was revealed in another study $^{5)}$ that the same choice of APW of proper $\mathrm{NaCl}$ concentrations was also required when fish were submitted to the detection. That is, $V$. anguillarum was detected more efficiently by the use of $0.5 \% \mathrm{NaCl}$ APW from sea water-reared

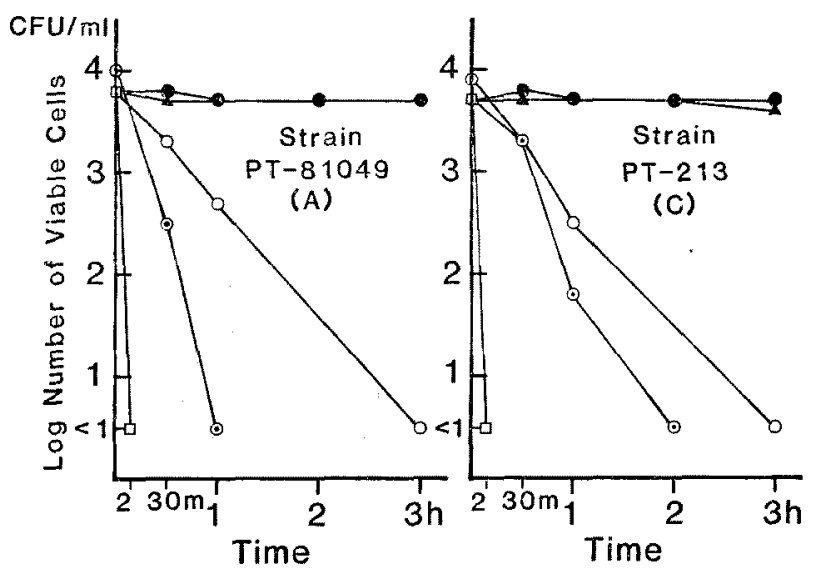

Fig, 4. Survival of $V$. anguillarum in various waters at $20^{\circ} \mathrm{C}$.

$-\bullet$ : sea water, $\Delta-\Delta$ : saline $(0.85 \% \mathrm{NaCl}), \bigcirc-0$ : freshwater (brook water), $\odot-\odot$ : freshwater (well water), $\square-\square$ : distilled water. 


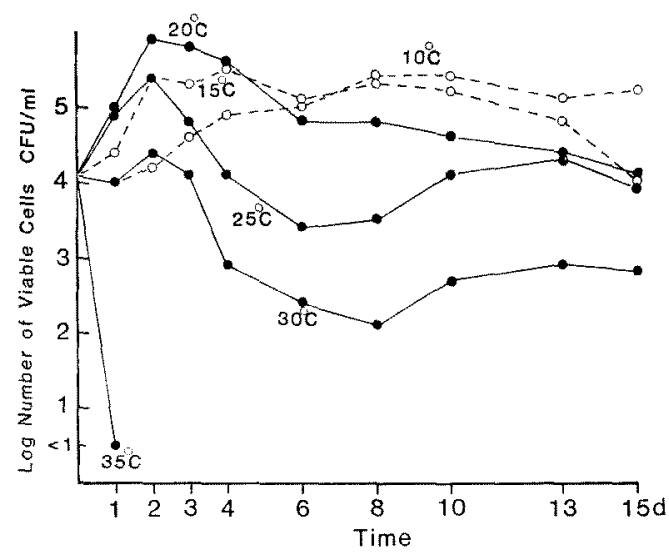

Fig. 5. Survival of V. anguillarum (PT-81049) in sea water at various temperatures.

fingerlings of ayu.

$V$. anguillarum was reported to grow well at $\mathrm{NaCl}$ concentrations from 0.5 to $3 \%{ }^{1,6,7)}$ The majority of bacteria existing in marine environment and sea water-reared fish are more or less halophilic, thus they can grow better at $3 \% \mathrm{NaCl}$ than at $0.5 \% \mathrm{NaCl}$. That may be the reason why $0.5 \% \mathrm{NaCl} \mathrm{APW}$ gave good results in the detection of $V$. anguillarum from sea waters.

According to our unpublished data, one moribund or freshly dead ayu, which was infected with a virulent strain of $V$. anguillarum, shed $10^{8}-$ $10^{7}$ viable cells of the organism in an hour in a freshwater aquarium. However, in the present study, $V$. anguillarum could not be detected from freshwater of the ponds even where vibriosis occurred among cultured ayu. This would be explained by the relatively small number of diseased fish in those ponds and rapid decrease in viable cell number of the pathogen in the freshwater ponds, as demonstrated experimentally in Fig. 4. Inability to survive of this pathogen in freshwater was also reported by others. ${ }^{8, \theta)}$

On the other hand, the organism was detected often from sea waters in the Inland Sea of Japan and its adjacent areas (Fig. 2). It is interesting that the bacterium was not isolated in the summer from July to September (Table 3). It is generally said that outbreaks of vibriosis are more common during the warmer months of the year. ${ }^{10)}$ Larsen $^{11}$ studied the prevalence of $V$. anguillarum like organism (VLO) in Danish coastal waters, and reported that the number of VLO increased in the spring and the level persisted to the autumn through the summer. But it should be emphasized that the water temperature did not exceed $20^{\circ} \mathrm{C}$

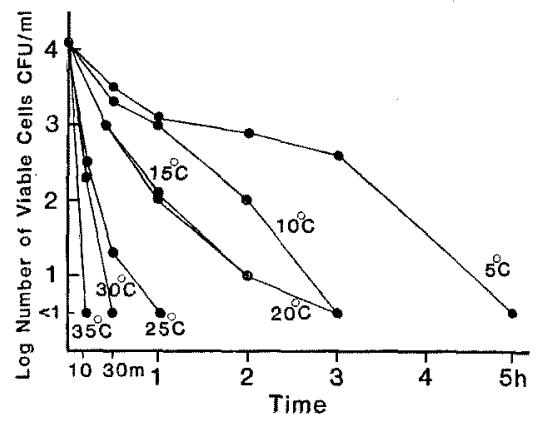

Fig. 6. Survival of $V$, anguillarum (PT-81049) in freshwater at various temperatures.

even in the mid-summer there. In our study area, the Inland Sea of Japan, the water temperature exceeds $20^{\circ} \mathrm{C}$ and sometimes it reaches $25^{\circ} \mathrm{C}$ or higher (Fig. 3) in summer. During these warmer period, $V$. anguillarum population may be overwhelmed by somewhat thermophilic vibrios such as $V$. parahaemolyticus ${ }^{12)}$ and $V$.alginolyticus. In the Inland Sea of Japan $V$. anguillarum infection in cultured yellow-tail prevails from May to July, but in August and September, when the water temperature rises higher, the vibriosis is usually superseded by pasteurellosis and streptococcosis. ${ }^{13)}$ This seems to be owing to the decrease in incidence of $V$. anguillarum in those warmest months.

In the present study, 89 strains of $V$. anguillarum were isolated, however, only 8 strains proved virulent $(8 / 60=13 \%)$ and 1 strain belong to the representative three serotypes $(A \sim C)(1 / 89=1 \%)$. As reported in the previous paper, about $60 \%$ of the strains isolated from wild fingerlings of ayu were virulent and agglutinated with the antisera of the three serotypes. ${ }^{2)}$ It is also empirically known that strains of $V$. anguillarum isolated from diseased fish are always capable of causing mortality in susceptible fish, and these strains belong to several limited serotypes represented by $A, B$, and $\mathrm{C}\left(\mathrm{J}-\mathrm{O}-1 \sim \mathrm{J}-\mathrm{O}-3 \mathbf{3}^{3,14,15)}\right.$ ) From these data, the following assumption can be made: $V$. anguilarum is ubiquitous in marine environments especially in coastal area and fish easily come into contact with the organism. Some forms of the whole population of the organism, presumably virulent forms or the forms having some kind of affinity for the host fish, can establish themselves on/in the host and remain even after the host 
migrates to the freshwater environment. And finally the virulent forms, serologically fall under the three virulent serotypes $(A \sim C)$ with a few exceptions, will cause disease coupled with lowered resistance of the host.

\section{Acknowledgements}

We would like to thank Mr. Y. Fukuura and Mr. A. Goh, the captain and the first officer of Toyoshio-maru for their kind help and advice during the research cruises. Dr. Y. Jo is also thanked for his assistance in the investigation in ayu ponds. This study was partly supported by a grant from the Fisheries Agency of Japan.

\section{References}

1) T. P. T. Evelyn: J. Fish. Res. Bd. Canada, 28, 517-525 (1971).

2) K. Muroga, H. Yamanoi, Y. Hironaka, S. Yamamoto, M. Tatani, Y. Jo, S. Takahashi, and H. Hanada: Bull. Japan. Soc. Sci. Fish., 50, 591596 (1984).

3) T. Kitao, T. Aoki, M. Fukudome, K. Kawano,
Y. Wada, and Y. Mizuno: J. Fish. Dis., 6, 175181 (1983).

4) T. Kitao, T. Aoki, and K. Muroga: Bull. Japan. Soc. Sci. Fish., 50, 1955 (1984).

5) M. Tatani, K. Muroga, T. Sugiyama, and Y. Hiramoto: Aquiculture (Japan), 33, 59-66 (1985).

6) K. Muroga and S. Egusa: Bull. Japan. Soc. Sci. Fish., 33, 636-640 (1967).

7) J. L. Larsen: J. Appl. Bact., 57, 237-246 (1984).

8) T. Itami and R. Kusuda: J. Shimonoseki Univ. Fish., 32, 33-39 (1984).

9) A. E. Tranzo, J. L. Barja, and F. M. Hetrick: Bull. Eur. Ass. Fish Path., 3, 43-45 (1982).

10) J. I. W. Anderson and D. A. Conroy: A Symposium on Diseases of Fishes and Shellishes (S. F. Snieszko ed.). Amer. Fish. Soc. Spec. Pub. No. 5, Washington, D. C., 266-272 (1970).

11) J. L. Larsen: Zbl. Bakt. Hyg. I. Abt. Orig. C3, 519-530 (1982).

12) T. Kaneko and R. R. Colwell: J. Bact., 113, 2432 (1973).

13) Y. Jo, K. Ohnishi, and K. Muroga: Fish. Path., 14, 43-47 (1979).

14) Y. Ezura, K. Tajima, M. Yoshimizu, and $T$. Kimura: Fish. Path., 14, 167-179 (1980).

15) Y. Jo: Shikoku Acta Medica, 37, 82-110 (1981). 